\title{
Amycolatopsis decaplanina sp. nov., a novel member of the genus with unusual morphology
}

Correspondence
Joachim Wink
joachim.wink@aventis.com

\author{
Joachim Wink, ${ }^{1}$ Julia Gandhi, ${ }^{2}$ Reiner M. Kroppenstedt, ${ }^{3}$ Gerhard Seibert, ${ }^{1}$ \\ Bettina Sträubler, ${ }^{3}$ Peter Schumann ${ }^{3}$ and Erko Stackebrandt ${ }^{3}$ \\ 1'Aventis Pharma Deutschland GmbH, Drug Innovation and Approval, Natural Products, 65926 \\ Frankfurt, Germany \\ ${ }^{2}$ School of Life Sciences and Chemical Technology, 535 Clementi Road, Singapore 599489 \\ ${ }^{3} \mathrm{DSMZ}$ - Deutsche Sammlung von Mikroorganismen und Zellkulturen GmbH, Mascheroder \\ Weg 1b, 38124 Braunschweig, Germany
}

In the course of a screening programme in Hoechst, Frankfurt, for new antibiotics that are active against methicillin-resistant strains of Staphylococcus aureus, the strain that produces the new antibiotic decaplanin (Eur. Pat., 1990, EP 356894) was isolated from a soil sample from India. Strain FH $1845^{\mathrm{T}}\left(=\mathrm{DSM} 44594^{\mathrm{T}}=\mathrm{NRRL}\right.$ B-24209 ${ }^{\mathrm{T}}$ ) displays activity against a wide range of Grampositive bacteria, including enterococci and clinical isolates, that are resistant to commonly applied antibiotics (Sanchez et al., 1992).

Micrographs of the strain described in this study are shown in Fig. 1. Morphological and physiological characteristics of DSM $44594^{\mathrm{T}}$ were observed on various agar cultures as described by Shirling \& Gottlieb (1966): yeast extract/malt extract agar (ISP 2), oatmeal agar (ISP 3), inorganic salt/starch agar (ISP 4), glycerol/asparagine agar (ISP 5), peptone/yeast extract/iron agar (ISP 6) and tyrosine agar (ISP 7), incubated for 10 days at $28^{\circ} \mathrm{C}$. For scanning electron microscopy (Grabley et al., 1992), the strain was grown on ISP 3 agar. A honey-yellow vegetative mycelium developed on all ISP media tested (RAL colour code 1005;

Published online ahead of print on 8 August 2003 as DOI 10.1099/ ijs.0.02586-0.

Abbreviation: $\mathrm{A}_{2} \mathrm{pm}$, diaminopimelic acid.

The GenBank/EMBL/DDBJ accession numbers for the 16S rRNA gene sequences of strains DSM $44594^{\top}$, DSM $44213^{\top}$ and DSM $43134^{\top}$ are AJ508237, AJ508236 and AJ577997, respectively.
Deutsches Institut für Gütesicherung und Kennzeichnung e.V. - Reichsausschuß für Lieferbedingungen). Aerial mycelium was only formed on ISP 3 medium and a soluble red pigment was produced on ISP 7 medium. After 710 days on ISP 3 medium, sporangium-like elements were formed. These elements showed a smooth surface and a regular shape under the scanning electron microscope. Spores were not detected either inside or outside the pseudosporangia.

Utilization of carbohydrates was investigated on ISP 9 medium (Shirling \& Gottlieb, 1966) by using a 12-well microtitre plate technique. Sodium chloride tolerance was also tested on 6-well microtitre plates by using a technique based on the method of Kutzner et al. (1986). A fingerprint of enzymic activities was obtained by using API 20E and API ZYM test strips (Smith et al., 1972; Humble et al., 1977; Kilian, 1978). Reactions are indicated in the species description.

To determine the antimicrobial spectrum (Williams et al., 1989), bacteria were grown on Mueller-Hinton agar and fungi on Czapek Dox agar. Antibacterial activity was seen after cultivation on ISP 2, ISP 3 and starch media, especially against Staphylococcus aureus, Micrococcus luteus, Streptomyces murinus and Bacillus subtilis. Antifungal activity was not detected.

For metabolite production, Amycolatopsis strains were incubated in four different media: a soymeal medium, a 


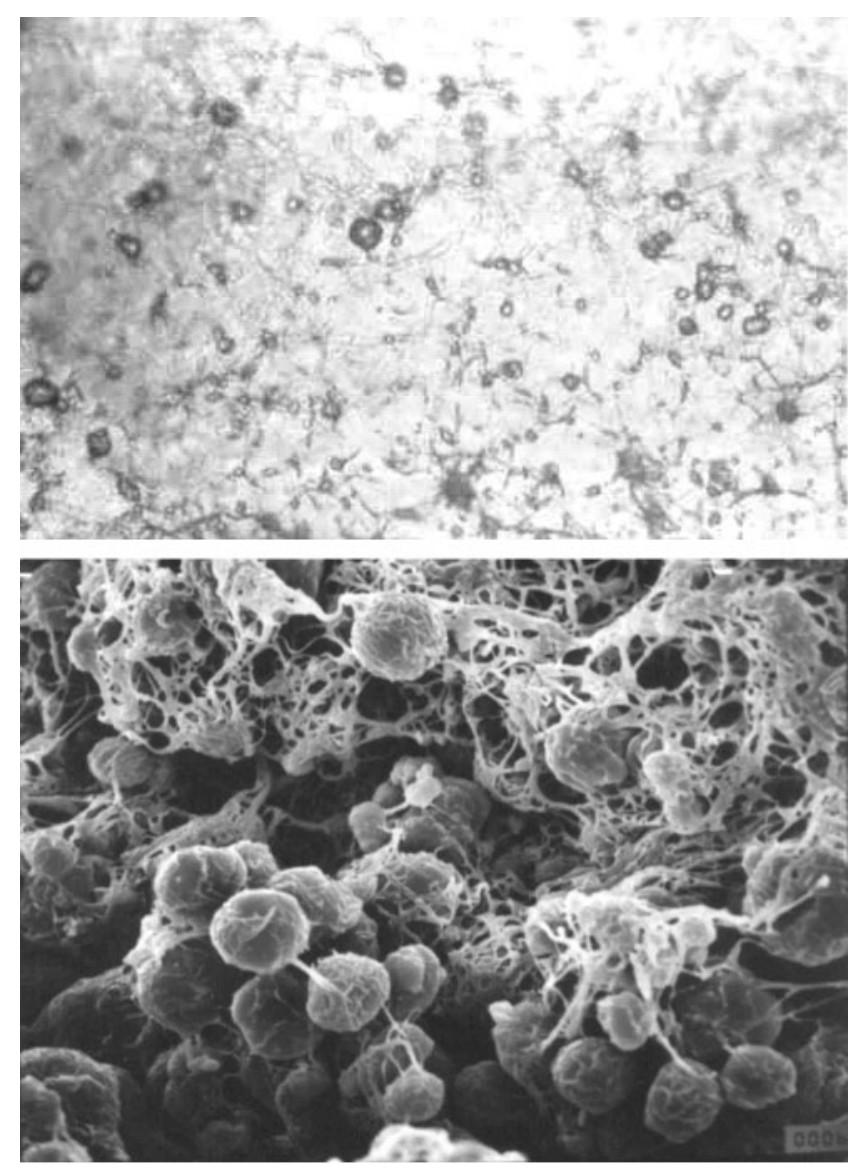

Fig. 1. Pseudosporangia formation in strain DSM $44594^{\top}$ grown on ISP 3 medium for 14 days at $28^{\circ} \mathrm{C}$. Top, light microscopy ( $\times 200)$; bottom, scanning electron microscopy $(\times 1000)$.

starch medium and ISP 2 and 3 media for 7 days in a shaking flask culture at $28^{\circ} \mathrm{C}$. After cultivation, the whole culture was extracted with methanol, evaporated and dissolved in water.

Analysis of whole-cell diaminopimelic acid $\left(\mathrm{A}_{2} \mathrm{pm}\right)$ isomers and sugars was done by the method of Hasegawa et al. (1983). Phospholipids and menaquinones were analysed by the method of Kutzner et al. (1986). To determine the whole-cell fatty acid profile, the fast method with trimethylsulfonium hydroxide (TMSH) was used (Müller et al., 1990). Major fatty acids were $\mathrm{i}^{-\mathrm{C}_{15: 0}}(22.5 \%), \mathrm{C}_{17: 0}$ $(11 \cdot 4 \%)$ and $\mathrm{i}-\mathrm{C}_{16: 0}(10 \cdot 3 \%)$, whilst $\mathrm{i}-\mathrm{C}_{14: 0}(6 \cdot 4 \%)$, ai$\mathrm{C}_{15: 0}(9 \cdot 4 \%), \mathrm{i}-\mathrm{C}_{15: 0} 2-\mathrm{OH}(8 \cdot 7 \%), \mathrm{C}_{15: 0}(7 \cdot 6 \%), \mathrm{C}_{17: 1}$ $(5 \cdot 8 \%), \mathrm{C}_{16: 0}(3 \cdot 3 \%), \mathrm{C}_{15: 1}(2 \cdot 1 \%), \mathrm{i}-\mathrm{C}_{17: 0}(1 \cdot 7 \%)$, ai- $\mathrm{C}_{17: 0}(3 \cdot 4 \%)$, i- $\mathrm{C}_{16: 0} 2-\mathrm{OH}(2 \cdot 8 \%)$, ai- $\mathrm{C}_{15: 0} 2-\mathrm{OH}$ $(1.9 \%), \mathrm{C}_{17: 0} \quad 2-\mathrm{OH}(1.5 \%)$ and 10 -methyl i-C $17: 0$ $(1 \cdot 2 \%)$ occurred in smaller amounts. Phospholipids were diphosphatidylglycerol, phosphatidylglycerol, phosphatidylethanolamine, hydroxyphosphatidylethanolamine phosphatidylinositol and phosphatidylinositol mannoside. Menaquinones were MK-8 $\left(\mathrm{H}_{4}\right)$ and MK-9 $\left(\mathrm{H}_{4}\right)$. The peptidoglycan diamino acid was meso- $\mathrm{A}_{2} \mathrm{pm}$; cell-wall sugars were arabinose and galactose.

Genomic DNA extraction, PCR-mediated amplification of the 16S rRNA gene and purification of PCR products were carried out as described previously (Rainey et al., 1996). The almost-complete 16S rRNA gene sequence of strain DSM $44594^{\mathrm{T}}$ (1464 nt) was aligned manually against $16 \mathrm{~S}$ rRNA gene sequences of representatives of the main actinobacterial lineages and then against members of the genus Amycolatopsis. Pairwise evolutionary distances were computed by using the correction of Jukes \& Cantor (1969). A phylogenetic dendrogram (Fig. 2) was reconstructed from the distance matrix by using the treeing algorithm of DeSoete (1983). Strain DSM $44594^{\mathrm{T}}$ was related closely to Amycolatopsis azurea DSM $43854^{\mathrm{T}}(99 \cdot 2 \%$ sequence similarity), Amycolatopsis orientalis IMSNU $20058^{\mathrm{T}}(99 \cdot 0 \%)$, Amycolatopsis japonica DSM $44213^{\mathrm{T}}(99 \cdot 1 \%)$ and Amycolatopsis keratiniphila DSM $44409^{\mathrm{T}}(99 \cdot 1 \%)$ (Al-Musallam et al., 2003). Sequence similarity values with less closely related members of the genus ranged between 95.0 and $98 \cdot 8 \%$.

Automated ribotyping of the isolates was accomplished by using the RiboPrinter (Qualicon) system (Bruce, 1996) and PvuII as the standard restriction enzyme for cutting genomic DNA. Whilst the patterns of the type strains of A. japonica and A. orientalis bear some similarity, those of other strains, including DSM $44594^{\mathrm{T}}$, are different (Fig. 3).

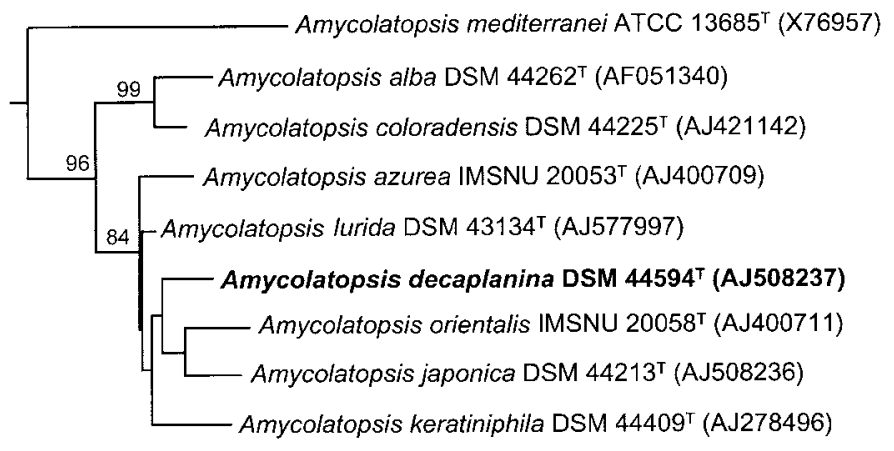

$1 \%$
Fig. 2. 16S rDNA dendrogram (DeSoete, 1983), displaying the phylogenetic position of strain DSM $44594^{\top}$ and phylogenetically related members of the genus Amycolatopsis. Numbers indicate percentages of 1000 bootstrap resamplings. More distantly related members of the genus served as a root. Bar, $1 \%$ sequence divergence. 
Amycolatopsis japonica DSM 44213 ${ }^{\top}$

Amycolatopsis lurida DSM $43134^{\top}$

Amycolatopsis keratiniphila DSM $44409^{\top}$

Amycolatopsis decaplanina DSM $44594^{\top}$

Amycolatopsis azurea DSM $43854^{\top}$

Amycolatopsis mediterranei DSM $43304^{\top}$
Fig. 3. Diversity of normalized Pvull ribotype patterns found within strain DSM $44594^{\top}$ and phylogenetically related Amycolatopsis strains.
For DNA-DNA reassociation experiments, DNA was isolated by using a French pressure cell (Thermo Spectronic) and was purified by chromatography on hydroxyapatite as described by Cashion et al. (1977). DNA-DNA hybridizations were carried out in duplicate, according to methods described by De Ley et al. (1970) and Huß et al. (1983), at $69^{\circ} \mathrm{C}$ in $2 \times$ SSC that contained $10 \%$ DMSO. Renaturation rates were calculated by using the computer program TRANSFER.BAS (Jahnke, 1992). DNA similarities were determined for strain DSM $44594^{\mathrm{T}}$ and its closest phylogenetic relatives. Strain DSM $44594^{\mathrm{T}}$ and $A$. azurea DSM $43854^{\mathrm{T}}$, which share high $16 \mathrm{~S}$ rRNA gene sequence similarity, showed $55 \cdot 7 \%$ DNA-DNA hybridization (mean of two determinations of $55 \cdot 2$ and $56 \cdot 2 \%$ ). Similarly low values were found for strain DSM $44594^{\mathrm{T}}$ and the type strains of $A$. orientalis DSM $40040^{\mathrm{T}}(50 \cdot 5 \%$, mean of 47 and $54 \%)$ and $A$. lurida DSM $43134^{\mathrm{T}}(31.5 \%$, mean of 32 and $31 \%)$. The type strains of the latter two species share only $44.5 \%$ DNA similarity. The remote DNA relatedness of organisms that share $>99.0 \% 16 \mathrm{~S}$ rRNA gene sequence similarity has recently been reported by Wink et al. (2003).

On the basis of 16S rRNA gene sequence similarity and chemotaxonomic properties, strain DSM $44594^{\mathrm{T}}$ is classified as a member of the genus Amycolatopsis. Species of this genus have not previously been described to form sporangium-like structures that are surrounded by a welldefined wall and in which spores are not observed. Strain DSM $44594^{\mathrm{T}}$ produces the glycopeptide antibiotic decaplanin. The formation of glycopeptide antibiotics has also been reported for some phylogenetically related species, such as vancomycin by $A$. orientalis (Pittenger \& Brigham, 1956), ristocetin by A. lurida (Grundy et al., 1956-1957) and azureamycin by A. azurea (Omura et al., 1979). Amycolatopsis mediterranei, on the other hand, being less closely related to these organisms, produces the antibiotic rifamycin.

Strain DSM $44594^{\mathrm{T}}$ differs from related Amycolatopsis species in cultural properties. Whilst the substrate mycelium is honey-yellow on all ISP media, A. azurea forms steelblue to purple-violet colonies, $A$. orientalis and $A$. lurida form yellow to beige colonies, $A$. japonica forms white colonies on some ISP media and Amycolatopsis keratiniphila has sand-yellow colonies. Based on carbohydrate utilization patterns and the API ZYM and API 20E panels (Table 1), strain DSM $44594^{\mathrm{T}}$ has highest similarity to
A. orientalis and A. lurida, but has more pronounced differences from $A$. azurea, A. japonica and other species (data not shown; Chun et al., 1999; Kim et al., 2002).

Stackebrandt \& Goebel (1994) recommended a binary threshold value of about $97 \%$ 16S rRNA gene sequence similarity between strains, above which it was advised to perform DNA-DNA reassociation experiments in order to determine whether or not organisms should be affiliated to the same species. Some members of the genus Amycolatopsis, however, are significantly more closely related than this by $16 \mathrm{~S}$ rRNA gene sequence similarity (around 99.0 \%), but DNA-DNA reassociation values are significantly below $70 \%$, the recommended threshold value for species delineation (Wayne et al., 1987). For example, Amycolatopsis methanolica NCIB $11946^{\mathrm{T}}$ and Amycolatopsis thermoflava NBRC $14333^{\mathrm{T}}$ share $99 \cdot 8 \%$ sequence similarity and the corresponding DNA-DNA binding value was $21 \%$; similarly, 16S rRNA gene sequence similarity between Amycolatopsis eurytherma NCIMB $13795^{\mathrm{T}}$ and strains NCIB $11946^{\mathrm{T}}$ and NBRC $14333^{\mathrm{T}}$ was also $99 \cdot 2 \%$ and the corresponding DNA-DNA binding values were 60 and $2 \%$, respectively (Chun et al., 1999; Kim et al., 2002). The phylogenetically closest neighbour of the decaplaninproducing strain DSM $44594^{\mathrm{T}}$ is A. azurea DSM $43854^{\mathrm{T}}$, which shares $99 \cdot 2 \% 16 \mathrm{~S}$ rRNA gene sequence similarity. Similar values were found for the type strains of $A$. orientalis and A. lurida. As the corresponding DNA-DNA reassociation value was determined to be $<56 \%$, we refrained from testing the binding rate for strain DSM $44594^{\mathrm{T}}$ and other Amycolatopsis species. We consider that strain DSM $44594^{\mathrm{T}}$ represents a distinct species with respect to phylogenetic position and genomic, morphological and metabolic uniqueness, for which we propose the name Amycolatopsis decaplanina sp. nov.

\section{Description of Amycolatopsis decaplanina sp. nov.}

Amycolatopsis decaplanina (de.ca.pla.ni'na. N.L. fem. adj. decaplanina formed from the name of the antibiotic decaplanin, which is produced by the organism).

Aerobic, non-motile, Gram-positive, catalase-positive actinomycete that forms extensively branched substrate mycelium. After 7-10 days on ISP medium 3, regularshaped to globose and smooth-surfaced sporangium-like elements (pseudosporangia) are formed. Spores are not 
Table 1. Utilization of carbohydrates and enzymic activities of strain DSM $44594^{\top}$ and type strains of related Amycolatopsis species

Taxa: 1, Strain DSM $44594^{\mathrm{T}} ; 2$, A. azurea DSM $43854^{\mathrm{T}} ; 3$, A.

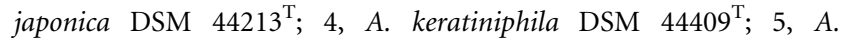
orientalis DSM $40040^{\mathrm{T}} ; 6$, A. lurida DSM $43134^{\mathrm{T}}$. All strains utilized glucose and arabinose and were positive for $N$-acetyl- $\beta$ glucosamidase, chymotrypsin and acid phosphatase activities, acetoin production and gelatinase. No strain utilized rhamnose and all were negative for $\beta$-glucuronidase, tryptophan deaminase and production of $\mathrm{H}_{2} \mathrm{~S}$ and indole.

\begin{tabular}{|c|c|c|c|c|c|c|}
\hline Substrate/activity & 1 & 2 & 3 & 4 & 5 & 6 \\
\hline \multicolumn{7}{|l|}{ Utilization of carbohydrates: } \\
\hline Sucrose & - & $+^{*}$ & $-\dagger$ & + & - & - \\
\hline Xylose & - & - & - & + & - & - \\
\hline Inositol & - & + & + & + & + & - \\
\hline Mannitol & + & - & + & + & + & + \\
\hline Fructose & + & - & + & + & + & + \\
\hline Raffinose & - & + & + & + & - & - \\
\hline Citrate & - & + & + & + & + & + \\
\hline \multicolumn{7}{|c|}{ Enzymic activities (API ZYM): } \\
\hline Esterase (C4) & - & - & + & + & + & - \\
\hline Esterase lipase (C8) & - & + & + & + & + & + \\
\hline Lipase (C14) & - & - & + & + & - & + \\
\hline Alkaline phosphatase & + & - & + & + & + & + \\
\hline Leucine arylamidase & + & + & + & + & - & + \\
\hline Valine arylamidase & + & - & + & + & - & - \\
\hline Cystine arylamidase & - & - & + & + & - & - \\
\hline Trypsin & + & + & + & + & - & + \\
\hline$\alpha$-Galactosidase & - & - & + & - & - & - \\
\hline$\beta$-Galactosidase & + & + & + & + & - & + \\
\hline$\alpha$-Glucosidase & + & + & + & + & - & + \\
\hline$\beta$-Glucosidase & + & + & + & + & - & + \\
\hline$\alpha$-Mannosidase & + & - & + & - & - & - \\
\hline$\alpha$-Fucosidase & - & - & + & - & - & - \\
\hline \multicolumn{7}{|l|}{ Enzymic activities (API 20E): } \\
\hline Arginine dihydrolase & - & + & + & + & + & - \\
\hline Lysine decarboxylase & - & + & + & + & - & - \\
\hline Ornithine decarboxylase & - & + & + & + & - & - \\
\hline Urease & + & + & + & + & - & + \\
\hline
\end{tabular}

* Similar to the growth that occurs in basal medium with glucose. $\dagger$ Growth is not better than that that occurs in basal medium with water.

detected either inside or outside the pseudosporangia. Colonies are honey-yellow on ISP media 1-7. Aerial mycelium is formed only on ISP medium 3. A soluble red pigment is only produced on ISP medium 7. Melanoid pigment is not produced. Carbohydrate utilization and enzymic relation towards the API ZYM and API 20E substrate panels are indicated in Table 1. Major fatty acids $(>10 \%)$ are $\mathrm{i}-\mathrm{C}_{15: 0}, \mathrm{i}-\mathrm{C}_{16: 0}$ and $\mathrm{C}_{17: 0}$. Menaquinones are MK- $8\left(\mathrm{H}_{4}\right)$ and MK- $9\left(\mathrm{H}_{4}\right)$. Produces the glycopeptide antibiotic decaplanin.
Type strain is $\mathrm{FH} \quad 1845^{\mathrm{T}} \quad\left(=\mathrm{DSM} \quad 44594^{\mathrm{T}}=\mathrm{NRRL}\right.$ B-24209 $)$. Isolated from soil in India.

\section{Acknowledgements}

We thank Hans Trüper for advice on the species name and Jolantha Swiderski for phylogenetic analyses.

\section{References}

Al-Musallam, A. A., Al-Zarban, S. S., Fasasi, Y. A., Kroppenstedt, R. M. \& Stackebrandt, E. (2003). Amycolatopsis keratiniphila sp. nov., a novel keratinolytic soil actinomycete from Kuwait. Int J Syst Evol Microbiol 53, 871-874.

Bruce, J. (1996). Automated system rapidly identifies and characterizes microorganisms in food. Food Technol 50, 77-81.

Cashion, P., Holder-Franklin, M. A., McCully, J. \& Franklin, M. (1977). A rapid method for the base ratio determination of bacterial DNA. Anal Biochem 81, 461-466.

Chun, J., Kim, S. B., Oh, Y. K. \& 7 other authors (1999). Amycolatopsis thermoflava sp. nov., a novel soil actinomycete from Hainan Island, China. Int J Syst Bacteriol 49, 1369-1373.

DeSoete, G. (1983). A least squares algorithm for fitting additive trees to proximity data. Psychometrika 48, 621-626.

De Ley, J., Cattoir, H. \& Reynaerts, A. (1970). The quantitative measurement of DNA hybridization from renaturation rates. Eur J Biochem 12, 133-142.

Grabley, S., Granzer, E., Hütter, K. \& 7 other authors (1992). Secondary metabolites by chemical screening. 8. Decarestrictines, a new family of inhibitors of cholesterol biosynthesis from Penicillium. I. Strain description, fermentation, isolation and properties. J Antibiot (Tokyo) 45, 56-65.

Grundy, W. E., Sinclair, A. C., Therriault, R. J., Goldstein, A. W., Ricker, C. J., Warren, H. B., Oliver, T. J. \& Sylvester, J. C. (1957). Ristocetin, microbiological properties. In Antibiotics Annual 19561957, pp. 687-698. New York: Medical Encyclopedia.

Hasegawa, T., Takizawa, M. \& Tanida, S. (1983). A rapid analysis for chemical grouping of aerobic actinomycetes. J Gen Appl Microbiol 29, 319-322.

Huß, V. A. R., Festl, H. \& Schleifer, K.-H. (1983). Studies on the spectrophotometric determination of DNA hybridization from renaturation rates. Syst Appl Microbiol 4, 184-192.

Humble, M. W., King, A. \& Phillips, I. (1977). API ZYM: a simple rapid system for the detection of bacterial enzymes. J Clin Pathol 30, 275-277.

Jahnke, K.-D. (1992). Basic computer program for evaluation of spectroscopic DNA renaturation data from GILFORD system 2600 spectrometer on a PC/XT/AT type personal computer. J Microbiol Methods 15, 61-73.

Jukes, T. H. \& Cantor, C. R. (1969). Evolution of protein molecules. In Mammalian Protein Metabolism, pp. 21-132. Edited by H. N. Munro. New York: Academic Press.

Kilian, M. (1978). Rapid identification of Actinomycetaceae and related bacteria. J Clin Microbiol 8, 127-133.

Kim, B., Sahin, N., Tan, G. Y. A., Zakrzewska-Czerwinska, J. \& Goodfellow, M. (2002). Amycolatopsis eurytherma sp. nov., a thermophilic actinomycete isolated from soil. Int J Syst Evol Microbiol 52, 889-894.

Kutzner, H. J., Kroppenstedt, R. M. \& Korn-Wendisch, F. (1986). Methoden zur Untersuchung von Streptomyceten und einigen anderen Actinomyceten, 4th edn. Report of the Institute for Microbiology, 
Technical University, Darmstadt and German Culture Collection. Braunschweig: DSMZ (in German).

Müller, K. D., Husmann, H. \& Nalik, H. P. (1990). A new and rapid method for the assay of bacterial fatty acids using high resolution capillary gas chromatography and trimethylsulfonium hydroxide. Zentbl Bakteriol 274, 174-182.

Omura, S., Tanaka, H., Tanaka, Y., Spiri-Nakagawa, P., Oiwa, R., Takahashi, Y., Matsuyama, K. \& Iwai, Y. (1979). Studies on bacterial cell wall inhibitors. VII. Azureomycins A and B, new antibiotics produced by Pseudonocardia azurea sp. nov. J Antibiot (Tokyo) 32, 985-994.

Pittenger, R. C. \& Brigham, R. B. (1956). Streptomyces orientalis, n. sp., the source of vancomycin. Antibiot Chemother 6, 642-647.

Rainey, F. A., Ward-Rainey, N., Kroppenstedt, R. M. \& Stackebrandt, E. (1996). The genus Nocardiopsis represents a phylogenetically coherent taxon and a distinct actinomycete lineage: proposal of Nocardiopsaceae fam. nov. Int J Syst Bacteriol 46, 1088-1092.

Sanchez, M. L., Wenzel, R. P. \& Jones, R. N. (1992). In vitro activity of decaplanin (M86-1410), a new glycopeptide antibiotic. Antimicrob Agents Chemother 36, 873-875.

Shirling, E. B. \& Gottlieb, D. (1966). Methods for characterization of Streptomyces species. Int J Syst Bacteriol 16, 313-340.
Smith, P. B., Tomfohrde, K. M., Rhoden, D. L. \& Balows, A. (1972). API system: a multitube micromethod for identification of Enterobacteriaceae. Appl Microbiol 24, 449-452.

Stackebrandt, E. \& Goebel, B. M. (1994). Taxonomic note: a place for DNA-DNA reassociation and 16S rRNA sequence analysis in the present species definition in bacteriology. Int J Syst Bacteriol 44, 846-849.

Wayne, L. G., Brenner, D. J., Colwell, R. R. \& 9 other authors (1987). International Committee on Systematic Bacteriology. Report of the ad hoc committee on reconciliation of approaches to bacterial systematics. Int J Syst Bacteriol 37, 463-464.

Williams, S. T., Goodfellow, M. \& Alderson, G. (1989). Genus Streptomyces. In Bergey's Manual of Systematic Bacteriology, vol. 4, pp. 2452-2492. Edited by S. T. Williams, M. E. Sharpe \& J.G. Holt. Baltimore: Williams \& Wilkins.

Wink, J. M., Kroppenstedt, R. M., Ganguli, B. N., Nadkarni, S. R., Schumann, P., Seibert, G. \& Stackebrandt, E. (2003). Three new antibiotic producing species of the genus Amycolatopsis, Amycolatopsis balhimycina sp. nov., A. tolypomycina sp. nov., A. vancoresmycina sp. nov., and description of Amycolatopsis keratiniphila subsp. keratiniphila subsp. nov. and A. keratiniphila subsp. nogabecina subsp. nov. Syst Appl Microbiol 26, 38-46. 